TEAM TEACHING WITH FILMS:

A COURSE ON SOUTHERN HERITAGE

\author{
Lawrence Clinton \\ East Texas State University
}

This paper is designed to describe an interdisciplinary team-teaching situation, to present the advantages and disadvantages of the team-teaching approach, and to explore the use of old films in teaching. The method of instruction was developed-initially for an undergraduate course at East Texas State University in the spring of 1977. "Southern Heritage in Fact and Fiction" was taught by three instructors who represented different disciplines within the university, and who varied in age and length of service to East Texas State. The instructors, Lawrence Clinton in Sociology, Don Reynolds in History, and Bill Jack in Literature, ranged in age from 35, to 47, to 54, respectively, in service to East Texas State 5, 12, and 23 years, respectively. These characteristics are presented to show that these instructors were not wide-eyed, bushy-tailed, over-enthusiastic fresh Ph.D.'s full of new ideas, rather they varied from a semi-bushy-tailed to two hard old hares.

The initial impetus to implement such a course came as a result of Clinton's and Jack's attendance at an off-campus faculty development retreat in the fall of 1976. After attending sessions on team-teaching and teaching styles, the decision was made to pursue the possibility of teaching a course in the spring semester and to develop the course to coincide with the theme of the annual Sam Rayburn Public Affairs Symposium. Since the theme of the Symposium was "The New South," Reynolds was asked to combine his expertise in Southern history, with Jack's specialty in Southern literature and films, and Clinton's interest in Southern race relations, in team-teaching a course on Southern heritage. Approximately one month after the retreat, the instructors and their respective heads of departments met with the Dean of Liberal and Fine Arts to discuss the feasibility of team-teaching such a course. The idea was accepted with the stipulation that students would enroll in the course under the three departmental listings and that the minimum enrollment for the course would be at least ten students in each of the three departmental sections.

\title{
PREPARATION AND FORMAT
}

After a week of intense planning, which began in early January, the course format and outline were established. It was obvious from the onset that the instructors varied not only in their areas of expertise but also in their areas of interest and desired methods of presentation. In examining the Southern heritage, Jack was interested not only in relating the literature about the South, but in presenting feature-length films depicting the South; Clinton was interested in exploring Black/White relations in the South; and Reynolds was concerned with the presentation of the essential historical background data. Thus, as a result of the combined interests of the instructors, the course outline was developed utilizing a historicaltopical framework. The instructors adopted Monroe Billington's The American South ${ }^{1}$ as the major text, and selected Intruder in the Dust, 2 Go Down, Moses, ${ }^{3}$ Inherit the Wind, 4 Woodward's The Burden of Southern History

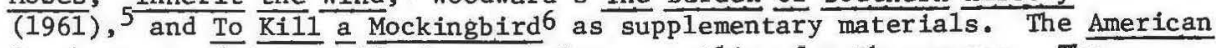
South was used as a guide in preparing an outline for the course. The historical-topical framework of this text allowed the course to span the period from Robert E. Lee to Jimmy Carter. The films that were selected were "Birth of a Nation," "Another Part of the Forest," "The Little Foxes," "Inherit the Wind," "Tobacco Road," "To Kill a Mockingbird," and "A11 the Kings Men." Although each instructor concentrated his efforts on certain areas of expertise for a designated number of class periods, some class sessions were also designed for joint instruction. Examinations and other class assignments were constructed and graded jointly by the instructors. 


\section{ORGANIZATION AND GOAL}

Team-teaching has been defined as "an organizational device by which a number of persons work together in a concerted effort to perform related instructional activities and to achleve common educational goals." 7 The major goal of the course was to separate fact from fiction about Southern heritage (religion, politics, economy, education, family) from the perspectives of sociology, literature, and history. The films and novels about the South were presented to depict the fictional aspects of the Southern heritage, and the instructors attempted to provide the factual aspects through their class lectures and discussions.

The class met three times a week, twice on Monday and once on Wednesday. Monday afternoon was devoted to the showing of films followed by class discussions, which afforded the instructors the opportunity to offer their different viewpoints and perspectives. The class ( 39 students) was divided among majors in sociology (ten students), literature (twelve students), history (eight students), and other disciplines (nine students).

\section{TYPICAL WEEK}

No real effort was made to balance the schedule in terms of instructors' responsibility. 8 The interest in certain areas was the major criterion used in class period assignments. The students seemed to enjoy the periods when joint instruction occurred, especially on those days when the instructors disagreed with each other.

During one week in March, for example, students were assigned to read To Kill A Mockingbird. On Monday morning Reynolds presented a lecture on Southern justice related to race relations. In the afternoon, the class viewed and discussed the film, "To Kill a Mockingbird." Following the film, the instructors highlighted different ideas and concepts touched upon by the film. Jack stressed the utilization of symbolism and pointed out certain symbolic inferences within the contents of the film; clinton presented ideas on collective behavior as related to race relations and compared a number of cases involving the lynching of Blacks in the state of Texas to the attempted lynching in the film; and Reynolds shared his view of the treatment or lack of treatment of the mentally $i l 1$ as depicted in the film. Then the students, who were presented a study guide related to the film, were allowed to comment on the film and ask questions of the instructors. On Wednesday Clinton presented a lecture on theories of prejudice and discrimination. Thus, the students were exposed to a novel, a film, and two lectures, and were involved in a class discussion encompassing the expertise of the three instructors, all within the time span of one week.

\section{STUDENT EVALUATIONS}

At the end of the course, the students were asked to comment upon several questions or statements about the course. Three of those questions were:

(1) What things (if any) were particularly useful or attractive about this course?

(2) What things (if any) were not particularly useful or attractive about this course?

(3) During this course you have viewed a number of films. Please note your general reaction to these films. 
Question One

Most students statements regarding the usefulness of the course reflected their generally positive reactions to the use of the films (23 students) and the team teaching approach (18 students). Selected student comments were as follows:

\footnotetext{
"I enjoyed a chance to correlate History, Sociology, and Literature."

"Diversity from the typical university routine."

"The lectures from different viewpoints were interesting and gave greater variety."
}

"The films were absolutely outstanding. They were helpful. Having three teachers, three separate and different points of view, was probably the best aspect of the course."

"There was the opportunity to see how three different subjects can so easily relate to one another."

"The films were very good, all were helpful in an attempt to show an idea or lifestyle."

"The offering of movies as an integral part of the course. The diversity of instruction."

\section{Question Two}

Some of the students' statements regarding the lack of usefulness of the course reflected their negative reactions to "an over-abundance of reading assignments" (ten students). Most students wrote that they found no aspects of the course distracting (25 students).

\section{Question Three}

Most statements regarding the use of "old" films reflected a generally positive reaction ( 30 students). Selected student comments were as follows:

"As I said they were one of the highlights of the course/the movies were al1 good."

"I enjoyed the films. They were representative of different eras and showed a variety of viewpoints."

"The films and the discussion of them were extremely helpful in tying in our lectures with one every day life - especially the subconscious aspect of it."

"I. enjoyed all the films very much. I really liked the Southern film festival during the Sam Rayburn Symposium."

"I got pleasure but also education from the films."

"The films helped greatly in putting class lectures to use. Even films that I had seen several times before, I saw in a different light this time."

"I learned much from the films." 
"Films are a marvelous teaching device."

"I really learned the feelings people possess about certain things and why they feel them. I also learned things about myself through the films."

"Excellent for their purpose."

"They helped my understanding of the course."

GENERAL IMPLICATIONS

Team Teaching

From this writer's perspective, after participating in the initial team-teaching experience and reviewing various articles related to teamteaching, certain advantages can be pointed out that are significant to participation in such an interdisciplinary approach. 9 Some of the advantages are outlined as follows:

(1) Instructors shared their knowledge.

(2) Instructors shared teaching techniques.

(3) Instructors were encouraged to do their best.

(4) Instructors were not locked within disciplinary boundaries.

(5) Students were exposed to interrelatedness of knowledge.

(6) Curriculum was developed and expanded by this approach.

(7) Students were exposed to different styles as well as perspectives in a classroom.

(8) Instructors had the opportunity to become better acquainted.

But there were also some disadvantages:

(1) Course planning was lengthy and difficult.

(2) Conflicts about grading standards and types of evaluations emerged. (The exams in the class were essay and each of the instructors graded each question. The average of the three scores was used. On several occasions there were big differences, but overall the scores were very close.)

(3) Freedom of action and innovation were limited once the course began because getting three people to meet and change format was difficult.

(4) Some students felt uneasy about not having "a teacher."

(5) The pressure of doing well was always present.

\section{Using Films}

In a retrospective look at the manner of course presentation, most students and the instructors were in agreement that the utilization of films represented a major asset to the quality of experience of the course. The films aroused a number of questions for exploration by the students. Did such films present a true picture of the South? How distorted were these films in their image of the South? Was there more to these films than met the eye? These questions were explored by the students and instructors on a weekly basis.

The visual images in regard to dress, environment, and sound provided insight that the texts lacked and opened areas for exploration as to the reality of a period. For example, the film "Inherit the Wind" describes the Monkey Trial in Tennessee, yet the historical "facts" in regard to why 
the case came about and the court room environment differ greatly from the film.

Some of the films invoked moods and emotionalized certain types of learning (history became alive). The trial scene in "To Kill a Mockingbird" produced a very sober mood in the class. It is one thing to read about or view statistics on differential treatment in the judicial system but another thing to live it via film.

The films were well received in this course for several reasons. First, the films were selected to reflect the assigned reading topics. Second, two days before each film students were given a 3-4 page handout explaining the essence of the film. Several study questions were also included. Third, the films, although old, were well done. Fourth, Jack's expertise in using films and analysis of films was appreciated by the instructors and students alike. And last, the films were entertaining.

The entertainment aspects caused some problems early in the course because students were not trying to analyze the messages of the film but were simply watching them. After several discussions about the purpose of using the films, the students seemed to respond.

\section{CONCLUSION}

"Southern Heritage in Fact and Fiction" provided an opportunity for a team-teaching approach with the use of films as a major educational feature of the course. The students expressed a viewpoint that the course provided a good platform for a successful approach to exploration of the facts and fictions of the Southern heritage. The students were exposed to several different perspectives on topics such as race relations, politics, education, economics, and religion. The students emphasized that the utilization of films was a positive feature of the course.

Although this paper provided no evidence that team-teaching or the utilization of old motion pictures worked better than a more traditional approach in the classroom, it does suggest that team-teaching using films was a worthy alternative teaching method. Other courses such as Western History, New England History, Great Plains History, or History of England and the British Empire could be developed using this approach. It is time for the teaching of history to come alive and for departmental walls to come down. Team-teaching using films is one way to accomplish those goals.

\section{NOTES}

${ }^{1}$ Monroe Billington, The American South (New York: Charles Scribners' Sons, 1971).

${ }^{2}$ William Faulkner, Intruder in the Dust (liew York: Vintage Books,
1948).

3 William Faulkner, Go Down, Moses (New York: Vintage Books, 1940).

${ }^{4}$ Robert E. Lee and Jerome Lawrence, Inherit the Wind (New York: Bantam, 1969).

${ }^{5}$ C. Vann Woodward, The Burden of Southern History (New York: Vintage Books, 1960). 
6 Harper Lee, To Kill a Mockingbird. (New York: Popular Library, 1962).

7 Horation M. LaFranci and Peyton E. Richter, Team Teaching at the College Level (New York: Pergamon Press, 1960).

${ }^{8}$ A course outline may be obtained by writing to Lawrence Clinton, Sociology, East Texas State University, Commerce, Texas 75428.

'LaFranci and Richter, passim.; Leslie Chamberlin, Team Teaching (Columbus: Charles Merri11, 1969); Medill Bain and Richard Woodar, Team Teaching in Action (Boston: Houghton-Mifflin, 1964). 